\title{
Finding Justifications for the Practice of Peace Journalism: A Public Assessment of Media Roles towards Peace Promotion in Nigeria
}

\section{Adelakun Lateef Adekunle*}

National Open University of Nigeria, Nigeria

*Corresponding author: Adelakun Lateef Adekunle, National Open University of Nigeria, Nigeria, Tel: 234 807-507-4; E-mail: delak058@yahoo.co.uk

Rec date: May 05, 2014; Acc date: May 28, 2014; Pub date: June 05, 2014

Copyright: (c) 2014 Adekunle AL. This is an open-access article distributed under the terms of the Creative Commons Attribution License, which permits unrestricted use, distribution, and reproduction in any medium, provided the original author and source are credited.

\begin{abstract}
The academic study of Peace Journalism across countries compels attentions as crises and wars abound. The argument for and against Peace Journalism is one of the fundamental issues among scholars on media involvement in peace keeping and peace building around the world. This study aimed to find justification for the practice of Peace Journalism in Nigeria by laying emphasis on the assessment of media roles in promoting peace without trampling on the ethics of the profession. It used survey method to examine how members of the public perceive mass media reports of crises in Nigeria. It also investigated whether or not the media reports during crises have elements of Peace Journalism. It again appraised the practice of Peace Journalism and its effect on peace promotion. The study found out that the pattern of media reports of crises in Nigeria is out of the context of Peace Journalism. Majority of the media practitioners take propaganda, stereotype and biased reports for Peace Journalism, thereby promoting crises rather than peace. The study recommended that the concept of Peace Journalism be redefined such that its objective is achieved. It also emphasized that Nigerian mass media should focus more on Investigative and Interpretative Journalism to ensure accurate and balance reports.
\end{abstract}

Keywords: Assessment; Peace journalism; Public perception; Mass media; Crises

\section{Introduction}

The argument for or against Peace Journalism is one of the fundamental issues among scholars on media involvement in peace keeping and peace building around the world. The understanding of Peace Journalism and how it is being practiced by various mass media especially in areas where wars and crises abound, measures to a certain degree media influence during crises and wars. Many journalists who based their practices on the tenet of the concept - "Bad News Makes Good News" - see Peace Journalism as alien to effective information dissemination because they consider horrible scenes, fatal accidents, crises, wars, and the likes as news that do not only interest the public but also sell. Many communication scholars, who have justified for or against the need for Peace Journalism, based the judgements on their views and perceptions of the concept. What is noted is that almost all the proofs or justifications either for or against Peace Journalism are rooted in media theories, ethics and laws. The major concern in this study is to find justification for the practice of Peace Journalism from media audience perspective by laying emphasis on the assessment of the media reports during crises, conflicts or attacks by various militant groups without trampling on the ethics of the profession or professional obligations.

Despite that, media report of crises, wars and militant attacks abound within and between countries thus leaving a wide gap between the practices of Peace Journalism and the effort towards ameliorating crises and wars. One of the fundamental objectives of the media emphasized in the Developmental Media theory is that, mass media should work towards development. Since peace is one of the foundations upon which development reclines, it implies that mass media should promote peace - not glamorizing crises and wars - to ensure development. This study is therefore not only to back or to reprove either of the views but also to establish public perceptions and assessment of Peace Journalism. The reason for this is that only in the consumers lies the evaluation of a product. The media consumers are the audience or the public and the assessment of the media roles in promoting peace lies in them. The basis for the public assessment is to substantiate or reprove the series of arguments from communication scholars and professionals.

\section{Statement of the Problem}

According to one of the recent authoritative sources, the Stockholm International Peace Research Institute's Annual report for 2008, world military spending by 2007 had reached $\$ 1.2$ trillion. This represents a 6 per cent increase in real terms over the previous year and a $45 \%$ increase over the ten-year period since 1988.American military spending for 2009 was expected to account for $44.4 \%$ of federal budget funds ( $\$ 1,066$ billion), with the annual intelligence budget amounting to around $\$ 30$ billion [1]. At the same time, just $\$ 284$ billion (11.8\%) was being directed at projects to eliminate poverty and $\$ 52$ billion (just $2.2 \%$ ) to education and jobs. Globally almost 1 (one) billion people are estimated to be living in poverty $[2,3]$.

In the Nigerian 2012 budget, security got the second highest allocation - about 7 per cent of the total allocation. This shows that much more is allotted to security than usual as a result of internal crises, insecurity and militant attacks within the country. Nigerian media were believed to be practicing Peace Journalism in order to control the crises and the incessant militant attacks. The belief turned out to be fallacy on 27th of April 2012 when the mass media itself became victims of the militant attacks as three media houses were attacked by members of Jama atu Ahlis SunnaLidda awati Wal-Jihad, otherwise known as Boko Haram [4]. 
In the 90s, there were series of comments and accusations against Nigerian media on issues concerning subjective reporting. What is amazing is that similar comments were made by members of the public, majorly on social media just after the attacks on three media houses (This Day, Sun and Moment Newspapers). The comments were not really justifying the attacks but rather calling on the 'to be objective in their reports in order to regain their fading-away credibility. This, according to them would enhance and substantiate Peace Journalism practice in Nigeria. A content analysis of the first two weeks editions of The Guardian and The Punch after the attacks on the three media houses shows that opinion and letter-to-the-editor pages are of similar context to that of social media. These are some of the impetuses that prompted this study.

\section{Research Questions}

This study attempted to find answers to some problems generated from the practice of Peace Journalism in Nigeria. The problems constituted the research questions as stated below:

- Do media consumers perceive any element of Peace Journalism in Nigerian mass media reports?

- Do the mass media patterns of reporting crises help to resolve the crises in Nigeria?

- Do men and women have different perceptions of media reports during crises?

- Do the media preferences (broadcast/print/social) affect the public perceptions of media reports during crises?

One of the reasons for the research questions above is to narrow down the study to problem-solving analysis.

\section{Significance of the Study}

This research is significant because it is an attempt to fine-tune the nitty-gritty of the concept of Peace Journalism in Nigeria and to set modality for its practice through audience oriented views so as not to spot the profession in the name of peacekeeping. The research would also call the attentions of the Nigerian journalists to the relevant public perceptions of the media reports in time of crises. It would also remind them of the essence of Peace Journalism and the need not to compromise the journalistic ethics in their reports. It would serve as reference points in academics and an avenue to savage unpatriotic media practitioners from jaundice journalism.

\section{Research Objectives}

The overall objective of the study was to find out if the pattern of Nigerian media reports fit in to Peace Journalism practice and why it has not help to curtail the crises as one of its objectives. It also aimed to assess public perception of the media reports during crises. It as well aimed at investigating and appraising the practice of Peace Journalism in Nigeria in order to corroborate its essence.

\section{Research Method}

Survey method was used to sample how 300 media audiences perceived media roles towards ameliorating crises in Nigerian [5]. The survey was conducted between December $13^{\text {th }} 2013$ and January $17^{\text {th }}$ 2014. The sampled audience also expressed their views about the media reports of crises as the basis for the assessment of the practice of Peace Journalism in Nigeria. Random probabilistic sampling technique was used to select the sample and structure questionnaires were used to generate data for the study. Statistical Presentation for Social Sciences (SPSS) programme was used to analyse the data and the findings were presented on frequency tables and charts where applicable [6].

\section{Literature Review}

One of the major problems facing many independent countries of the world today is internal crisis that always result in wars and insecurity. This single trauma has done a lot of havoc to sectors like economy, health, education, and many others thereby causing setbacks to national efforts towards development. What is noted is that much of the efforts towards development revolve round the economy. Except in recent time, when health received much attention as a result of its adverse implications on economy. Lately, there is significant shift of the media attention to crises management and peace building as a result of insecurity and attacks by various militant groups that abound particularly in Nigeria.

The key role of mass media is to inform though, different categories of audience derive other benefits from the information depending on why they go to a particular medium of mass communication [7]. Information from mass media may educate, entertain, orientate, and may even lead to individual, national and international development. There are also media theories that define media roles and operations in different circumstances. For example, media effect theories discuss the power of mass media to cause changes or to make effects. Mass media are today used as one of the inputs to resolve problems within and between societies. Communication for peace is seen as a subset of communication for development. Under this section of the study, various understanding and few of the scholars' arguments revolving round the concept of Peace Journalism would be reviewed to:

- juxtapose the arguments for and against the practice of Peace Journalism

- establish if truly Peace Journalism has helped in conflict control

\section{Concept of Peace Journalism and the Impact on Truth and Objective Reporting}

Peace Journalism is the practice of media reports of crises, violence, or other related activities that are likely to disrupt the peaceful coexistence of the inhabitants in a way that will lessen both its immediate and aftermath effects. Galtung [8] agrees that since the concern of a disease journalist is not to highlight how diseases might be overcome, except by means as violent as the disease itself. Similarly, the concern of Peace journalists should not be only to resolve crises but also to guide their reports towards preventing crises and ensuring reconciliation for development.

Among the proponents of Peace Journalism, Jake Lynch [9], like many others, based his argument on the ethics of the profession which preach impartiality and objectivity as a route toward peace building.

According to Lynch [10], Peace Journalism proposes a set of distinctions in the reporting of conflicts, as well as a workable set of methods for editors and reporters to employ, based on an awareness of these distinction, in mainstream news and current affairs. Whereas War Journalism leads - or leaves - readers and audiences to overvalue violence, as a response to conflicts and crises, Peace Journalism creates opportunities for society at large to consider and value nonviolent, developmental responses. 
He submitted that Peace Journalism tends to:

- Take an analytical approach to conflict, seeking opportunities to parties, goals, needs and interests;

- Project a multiparty conflict model rather than a Manichean tugof-war;

- Find room for perspectives from beyond the usual 'official sources; and

- Seek out peace initiatives as well as 'pegs' (opportunities) to report on them
From the Lynch [11] submission and other evidences, objectivity, which is one of the key measures of professional journalism, is the bone of contention between the advocates of Peace Journalism and their counterparts. One of the advocates, Samuel Peleg [12], argues that:

Preventing conflicts is everyone who can job; and journalists, with their potential to influence public opinion, certainly can.

\begin{tabular}{|c|c|c|c|c|c|c|}
\hline \multicolumn{7}{|l|}{ Descriptive Statistics } \\
\hline How do you consider media practice during crises in Nigeria & $\mathrm{N}$ & Minimum & Maximum & Mean & Std. Deviation & Decision \\
\hline Media reports of crises are balanced & 300 & 1 & 5 & 3.57 & 1.198 & Rejected \\
\hline Media reports of crises are adequate & 300 & 1 & 5 & 2.48 & 0.952 & Accepted \\
\hline Media reports of crises are well-researched & 300 & 2 & 5 & 3.76 & 0.823 & Rejected \\
\hline Media reports of crises are problem-solving oriented & 300 & 2 & 5 & 3.75 & 0.817 & Rejected \\
\hline $\begin{array}{l}\text { Media reports of crises do not glamorize crises which can increase tension in the } \\
\text { country }\end{array}$ & 300 & 2 & 5 & 3.65 & 0.982 & Rejected \\
\hline Media reports of crises do not incite parties involved against one another & 300 & 2 & 4 & 3.64 & 0.687 & Rejected \\
\hline Media reports of crises are truth & 300 & 1 & 5 & 2.95 & 1.213 & Rejected \\
\hline Media reports of crises are not political & 300 & 3 & 5 & 4.12 & 0.6 & Rejected \\
\hline Mass Media pay attention to peace stories and post war development & 300 & 3 & 5 & 3.88 & 0.6 & Rejected \\
\hline Media reports of crises expose lies and impending danger & 300 & 2 & 4 & 3.51 & 0.701 & Rejected \\
\hline $\begin{array}{l}\text { Media reports present causes and options on every side to a crises so as to portray } \\
\text { conflict in realistic terms }\end{array}$ & 300 & 1 & 5 & 3.12 & 1.267 & Rejected \\
\hline Media reports of crises offer creative ideas for conflict resolution & 300 & 2 & 4 & 3.75 & 0.666 & Rejected \\
\hline Media reports of crises reveal excesses committed by people of all parties & 300 & 2 & 5 & 3.49 & 1 & Rejected \\
\hline Media reports of crises do not violate the ethics of the profession & 300 & 1 & 4 & 2.52 & 1.039 & Rejected \\
\hline Media reports of crises are not judgemental & 300 & 2 & 5 & 2.98 & 1.112 & Rejected \\
\hline Media reports of crises are not detrimental to National Security and unity of the country & 300 & 1 & 4 & 2.3 & 1.065 & Accepted \\
\hline Valid N (list wise) & 300 & & & & & \\
\hline
\end{tabular}

Table 1: Audience Perception of Media Reports during Crises.

Samuel Peleg [12] quoting Gamson and Modilgiani describe journalists as "political sponsors", who update their reader's political agenda, stimulate their worldview and inspire opinions and values. Through this, he believes that journalists contribute a great deal to the contraction of conflict by shrinking public support to leaders and initiatives which espouse belligerent tendencies.

While emphasizing his justification for Peace Journalism, Professor of Peace Studies at Granada and Director of TRANSCEND, a global peace and development network, Galtung[8] agrees that there is no argument that violence should not be reported. But the first victim in a war is not truth - truth is only the second victim. The first victim is, of course, peace.

The former UN Secretary General, Kofi Annan also agrees that: 'By giving voice and visibility to all people - including and especially the poor, the marginalized and members of minorities - the media can help remedy the inequalities, the corruption, the ethnic tensions and the human rights abuses that form the root causes of so many conflicts Goretti [13].

For many journalists, the very idea of media-based intervention in situations of conflict is against the ethos of 'objectivity' and 'neutrality' fundamental to their profession. Majority of those that oppose Peace Journalism argued that the issue is not about taking sides in reporting conflict, since journalists are a third party in any conflict they are covering. Constant subjective decisions that are necessarily made at every stage of a journalist's work make it apparent that assumptions of objectivity need to be taken with serious criticism and scepticism. These decisions include how one chooses the topics to be reported, the particular elements of the story that 'ought' to be stressed, which 
interviewees are chosen and the particular parts of interviews quoted, the photographs to accompany the text, the overall presentation of the text, and finally the editorial decisions themselves.

All of these, point to the ways in which journalists can only subjectively report events, and the fact that this subjectivity will be partly defined by their perceived role and stance in the conflict in question. Even by choosing to report or not to report a particular situation, journalists may impact its outcome. Many of these are noticed in what Shinar [14] uses to distinguish Peace Journalism as shown below:

- Exploring backgrounds and contexts of conflict formation, and presenting causes and options on every side so as to portray conflict in realistic terms, transparent to the audience.

- Given voice to the views of all rival parties.

- Offering creative ideas for conflict resolution, development, peacemaking and peacekeeping.

- Exposing lies, cover-up attempts and culprits on all sides, and revealing excesses committed by, and suffering inflicted on, people of all parties.

- Paying attention to peace stories and post-war developments.

By contrast, the opponents of Peace Journalism raise a number of objections. According to them Peace Journalism is an unwelcome departure from objectivity and towards a journalism of attachment; it mistakenly assumes powerful and linear media effects; it is a normative model, rooted in the discipline of peace research, that fails sufficiently to take into account the constraints imposed by the actual dynamics of news production (including professional values and organizational imperatives), and hence, may have little to offer journalists in practice [15].

Going by these arguments, one may be forced to demand an explanation on whether what is presently being practiced by the Nigerian mass media could be regarded as Peace Journalism [16]. Or, something similar to what Herman and Chomsky [17]regard as the dominant American media as comprising a single propaganda system in which "money and power are able to filter out the news fit to print, marginalize dissent, and allow the government and dominant private interests to get their messages across to the public." The reports of the Nigerian media on crises most especially Boko Haram insurgence are often one-sided; sometimes what the media considered good for the public and not what the stories really are; most often what sells the media and not what promotes the media vision on the social responsibility goals; and what the powerful influential including the governments, politicians and their political allies, corporate organization and conglomerates as well as media owners, considered favorable to their political, social and economic gains.

Another emphasis in the justification for or against Peace Journalism is whether or not mass media could still maintain the ethics of the profession while trying to perform social responsibility of promoting peace, controlling crises, wars, and attacks [18]. It is noted in the comment of Kuusik [19] that Journalism does not need justification for its existence. Its service to society is justification in itself. Going by Kuusik's [19] comments, it implies that truly Peace Journalism can be good (suppresses tension and crises) or bad (glamorizes wars, crises and militant attacks) depending on how it is being practiced. Then, Reliable, accurate and objective media, be it mainstream, alternative or traditional/nonconventional media, can both prevent and resolve conflict through the automatic functions of responsibly disseminating information, furthering awareness and knowledge, promoting participatory and transparent governance, and addressing perceived grievances [20]. In this regard, the effects of media on conflict can be viewed both in terms of the negative repercussions that inadvertent or overt propagandistic media may have in terms of fuelling tensions and provoking conflict, as well as the potential positive impact it may have if based on basic professional standards, combined with diverse access to information, reasonable financial resources and adherence to ethical codes. Such media can contribute to societal reconciliation, change misperceptions and broaden understanding of the causes and consequences of conflict, Hackett [21]

\section{Theoretical Perspective}

Peace Journalism is the major concern of the mass media now that restoration of peace has become a dare need of the public in the crises areas. It remains the goal and interest of the public, facilitated by the mass media. It is indisputable that development would continue to crawl in a society where crises and insecurity take the place of peace and security. Development Media Theory does not only showcase media roles towards development but also block alien factors such as crises, wars and the likes that are likely to impede development.

Beyond bringing matters to the public domain, Akinfeleye [22], cited by Mustapha in Nwosuet al. [23] views the roles of the mass media in development from the social responsibility perspective. $\mathrm{He}$ agrees that mass media serve as common carrier of ideas and information, particularly on development issues, give representative, unbiased and accurate picture of the goal aspiration and socialphilosophical foundation of the society in which they operate.

Another theory that explains media influence and impact on the publics is Agenda Setting of the Media. The objective of Agenda setting is cause-and-effect relationship between media agenda and public agenda. What is agenda setting?

Introduced in 1972 by Maxwell McCombs and Donald Shaw in their ground breaking study of the roles of the media in 1968 presidential campaign in Chapel Hill, North Carolina, Agenda Setting theory dwells much on what information the media give prominence to. Such information is what the members of the public discuss. The functions of setting agenda concern much the well-acquainted media, (Television, Radio, and Newspaper). A lot of issues on the net originated from the public. Information about job vacancies is what the job seekers want and what the employers have to send to the media. This shows that not only the mass media set agenda, interest groups and other members of the public also do set agenda. In some cases, pressure groups or special interest groups are able to boost an issue onto the media agenda. Researchers are now moving beyond the study of the formation of the agenda by the press to consider how ideas of agenda setting might be applied in ways to make society work better.

\section{Carter et al. [24], argues that:}

The study of agenda setting needs to advance beyond furnishing better measure of the media current effects. We need to understand agenda setting well enough to suggest what the media might do, that would improve the public's capability to think together about its common problems.

Therefore, if people are exposed to the same media, they may or may not place importance on the same issue. It is not indisputable that mass media place emphasis on the message they want the public to 
discuss as they currently do on the Boko Haram insurgence. Everyone would believe that mass media have succeeded in what they want the public to think about (peace or insecurity) but how they want the public to think about it, is still debatable.

\section{Data Analysis and Discussion of Findings}

Nineteen variables including demographic variables of the responded were analyzed to answer the research questions set. The respondent's views and perceptions of the subject matter, Peace Journalism, were tested on a Like rt Scale. Only the most relevant charts and tables were presented while others were subsumed in the discussion.

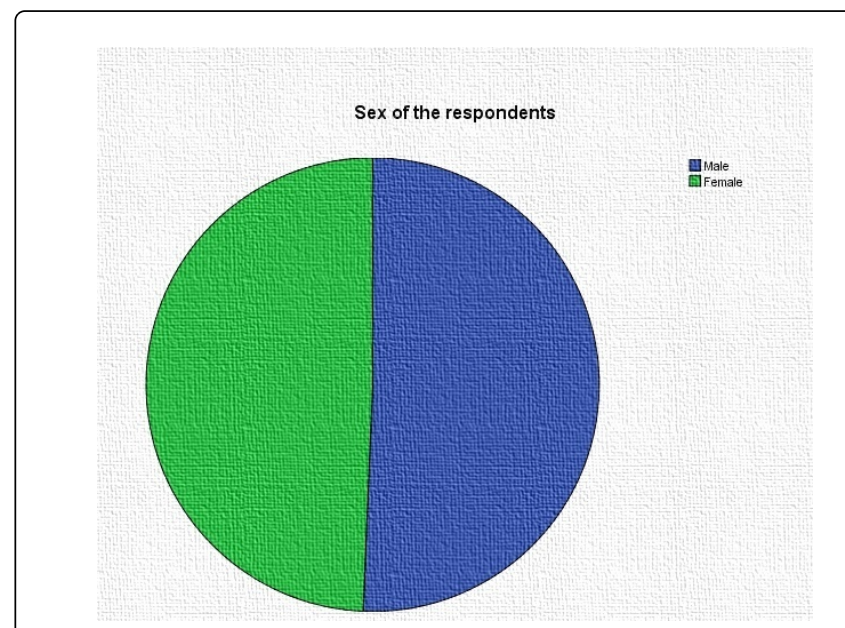

Figure 1: Sex of the Respondents.

As shown in the pie chart above (Figure 1), the ratio of male to female respondents is slightly above average. This implies that there are few more male than female in the numbers of respondents.

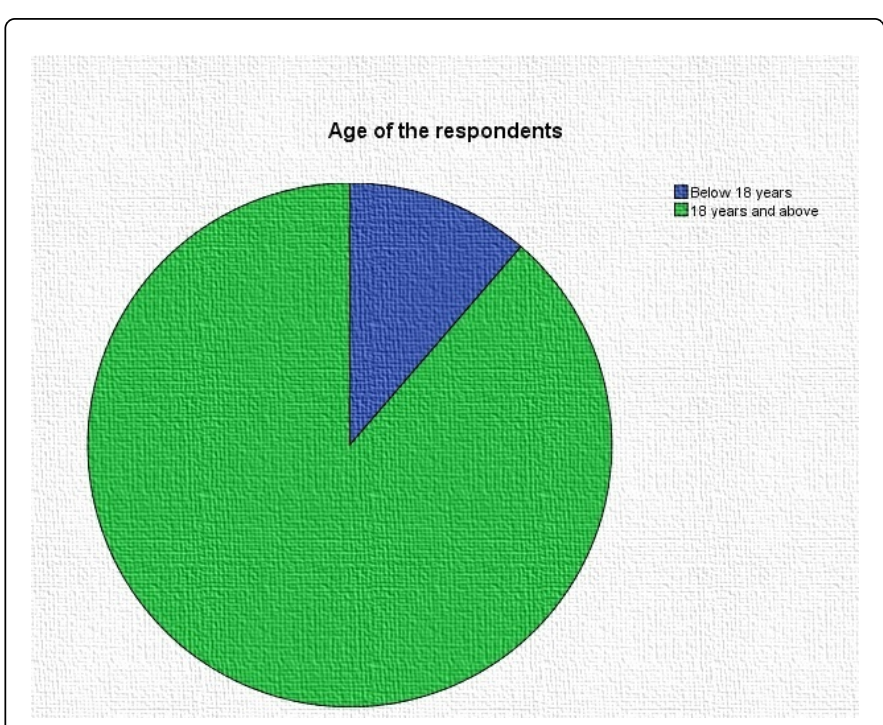

Figure 2: Age of the Respondents.

(Figure2) above shows that the overwhelming majority of the respondents are above 18 years of age. This is an indication that those interviewed are matured to evaluate the mass media reports on various crises within the country.

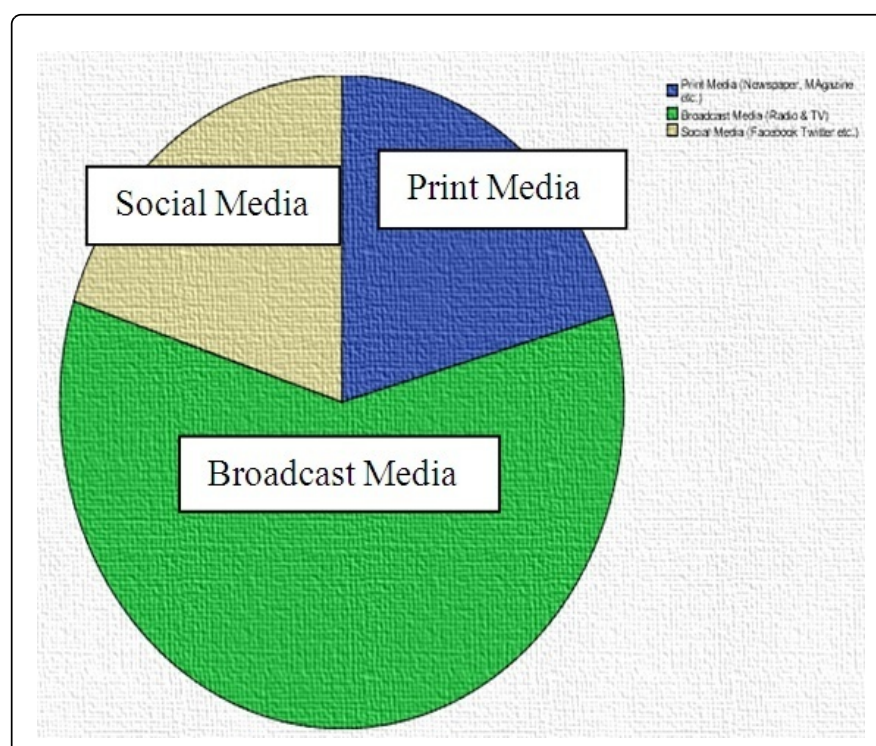

Figure 3: Respondent preferred media of information.

As reflected in the chart three above (Figure 3), about three out of every five of the respondents prefer broadcast media as sources of media information. This is an indication that radio and television are still popular media of information among the Nigerian media audience. The audio-visual and motion advantages of the media are most often regarded as the basis. Exactly one-fifth of the respondents prefer social media while slightly above the number prefer print media.

All the sixteen variables presented in Tablel above are the indicators of Peace Journalism. The variables are positive statements about Peace Journalism and the media audience assessed the statement on five level of like rt scale. The mean scores were used to measure the acceptability or otherwise of the variables. Between 0 and 2.5 shows that the respondents accept the variable while the mean score above 2.5 shows that the variable is rejected. The mean scores also show the degree of acceptance or rejection of the variables. As the mean score increases from zero up to 2.5 , the degree of acceptance of the variables decreases but as the mean scores increase from 2.5 up to 5 , the degree of rejection of the variables increases.

\section{Answering the Research Questions}

\section{Research Question 1}

Do media consumers perceive any element of Peace Journalism in Nigerian mass media reports?

The media audience do not consider the media reports of crises in Nigeria as Peace Journalism as presented in the first research question of the study. The mass media are lost in the understanding of the concept as they glamorize crises with banner headlines accompanied with gory pictures or scenes. Many of the indicators of Peace Journalism assessed by the media audience proved that the pattern of media reports of crises in Nigeria cannot be regarded as Peace Journalism. 
Page 6 of 7

\section{Research Question 2}

Do the mass media patterns of reporting crises help to resolve the crises in Nigeria?

As revealed in (Table 1), Nigerian mass media do not pay much attention to peace stories and post crises development. It was also revealed that Media reports of crises do not offer creative ideas for conflict resolution [25]. Again, media reports neither, present causes and options on every side to crises so as to portray conflict in realistic terms nor expose lies and impending danger as a result of their deficient in Investigative Journalism or low research effort. As a result of this, media effort towards peace promotion is not well felt.

\section{Research Question 3}

Do men and women have different perceptions of media reports during crises?

\begin{tabular}{|c|c|c|c|c|c|}
\hline \multicolumn{6}{|c|}{ Media audience perception of media reports during crises ${ }^{*}$} \\
\hline & & & Positive perception & Negative perception & Total \\
\hline \multirow{4}{*}{ Sex of the respondents } & \multirow{2}{*}{ Male } & Count & 34 & 118 & 152 \\
\hline & & $\%$ of Total & $11.30 \%$ & $39.30 \%$ & $50.70 \%$ \\
\hline & \multirow{2}{*}{ Female } & Count & 33 & 115 & 148 \\
\hline & & $\%$ of Total & $11.00 \%$ & $38.30 \%$ & $49.30 \%$ \\
\hline \multirow{2}{*}{\multicolumn{2}{|c|}{ Total }} & Count & 67 & 233 & 300 \\
\hline & & $\%$ of Total & $22.30 \%$ & $77.70 \%$ & $100.00 \%$ \\
\hline
\end{tabular}

Table 2: Sex of the respondents ${ }^{*}$ Media audience perception of media reports during crises. (Cross tabulation) ('All variables in Table 2 were collapsed and recoded to arrive at the variable)

As noted earlier that sex distributions of the respondents are almost evenly distributed, the perceptions of media reports by both sexes are also almost at par. Almost similar percentages of both genders have positive perception of media reports of crises. Similar case is noted in column of negative perception though more than three-quarters of the total respondents have negative perception of the media reports of crises in Nigeria. This implies that gender has no effect on the public perceptions of the media reports during crises.

\section{Research Question 4}

Do the media preferences (broadcast/print/social) affect the public perceptions of media reports during crises?

As reflected in Table 3, about one-third of the respondents, who preferred print media have positive perceptions of the media reports during crises while a bit less than one-quarter of those who preferred broadcast media have positive perception of media reports of crises. The case of those who preferred social media is similar to that of print media in which about one-third have positive perception of the media reports of crises. It implies that media preference has little effect on the audience perception of media reports of crises.

\section{Conclusion}

The roles of the mass media in all facets of human life are highly important as the mass media are one of the key agents of development. The power of mass media to aid development is not contestable but how it exercises the power at a particular time, place and circumstance to achieve the objective calls for attention. The practice of Peace Journalism to resolve crises and wars is not an unwelcomed development in media practice considering the havocs often recorded after every crisis and attack. This study found out that the pattern of media reports of crises in Nigeria is out of the context of Peace Journalism. It invariably implies that majority of Nigerian media practitioners either misconstrue the concept or deliberately sabotage the objective of the concept for self-reason(s) [26].

\section{Recommendation}

Base on the findings of this study, the concept of Peace Journalism needs to be redefined so that Nigerian media practitioners would have a sense of focus while reporting crises and related issues. Peace Journalism practice should be regarded as a mean to achieve the ends goal - suppressing crises and promoting peace. The end should not be used to justify the means. No matter the pressure from or interest of the public, interest groups and governments, both the ends and the means to achieve it must be justified.

Besides, the ethics of the profession should be prioritized by censoring media reports in line with the professional ethics to ensure that they are not only of good taste but also free of ethical flaws. The regulatory body should intensify its regulatory efforts by sanctioning erring media houses to serve as deterrent and as well commending those which observe the media ethics.

Internal conflicts do not occur spontaneously but tend to have a history. Nigerian media usually have a deeper understanding of the existing political structures, the participants of the conflict as well as the changes preceding the outbreak of violence. The media can therefore, not only influence society before the conflict by recognizing and properly addressing the issues but also afterwards. Kuusik [19] emphasises that Mass Media have the ability to accelerate and magnify fears or reduce them. Nigerian Media therefore need to defuse tensions before they even reach a critical point and keep a critical eye on government, opposition and society. By supplying credible information and reaching a large audience, the media help in managing conflicts. They also need to encourage reconciliation and societal development after the crises. 
Citation: Adekunle AL (2014) Finding Justifications for the Practice of Peace Journalism: A Public Assessment of Media Roles towards Peace Promotion in Nigeria. J Mass Communicat Journalism 4: 193. doi:10.412/2156-7912.1000193

Page 7 of 7

\begin{tabular}{|c|c|c|c|c|c|}
\hline \multicolumn{6}{|c|}{ Media audience perceptions of media reports during crises ${ }^{*}$} \\
\hline & & & Positive perception & Negative perception & Total \\
\hline \multirow{6}{*}{ Respondent preferred media of information } & \multirow[b]{2}{*}{ Print Media (Newspaper, Magazine etc.) } & Count & 15 & 47 & 62 \\
\hline & & $\begin{array}{ll}\% & \text { of } \\
\text { Total } & \end{array}$ & $5.00 \%$ & $15.70 \%$ & $20.70 \%$ \\
\hline & \multirow[b]{2}{*}{ Broadcast Media (Radio \& TV) } & Count & 38 & 140 & 178 \\
\hline & & $\begin{array}{ll}\text { \% } & \text { of } \\
\text { Total } & \end{array}$ & $12.70 \%$ & $46.70 \%$ & $59.30 \%$ \\
\hline & \multirow[b]{2}{*}{ Social Media (Facebook Twitter etc.) } & Count & 14 & 46 & 60 \\
\hline & & $\begin{array}{ll}\% & \text { of } \\
\text { Total }\end{array}$ & $4.70 \%$ & $15.30 \%$ & $20.00 \%$ \\
\hline \multirow{2}{*}{ Total } & & Count & 67 & 233 & 300 \\
\hline & & $\begin{array}{ll}\% & \text { of } \\
\text { Total } & \end{array}$ & $22.30 \%$ & $77.70 \%$ & $100.00 \%$ \\
\hline
\end{tabular}

Table 3: Respondent preferred media of information ${ }^{*}$ Media audience perception of media reports during crises. (Cross tabulation) ( ${ }^{*}$ All variables in Table1 were collapsed and recoded to arrive at the variable)

\section{References}

1. Woodward B (2004) Plan of Attacks, Simon and Schuster, London.

2. Haider R (2008) Global Poverty Figures Revised Upward, One World US.

3. Keeble R, Tulloch J, Zollman F (2010) Peace Journalism, War and Conflict Resolution. Peter Lang Publishing Inc, New York.

4. Madunagu E (2012) Why We Attacked This Day - Boko Haram. The Punch27: 1-2.

5. Osuola EC (1990) Introduction to Research Methodology. Onitsa, African-fep Publishers.

6. Esan EO, Okafor RO (1995) Basic Statistical Methods, Lagos. JAS Publishers.

7. Wilmmer R, Dominick J (2006) Mass Media Research, California, Wadsworth publishing Co.

8. Galtung J (1998) High Road, Low Road: Charting the Course for Peace Journalism. Springer 5: 95-102.

9. Lynch J, McGoldrick A (2005) Peace Journalism. Hawthorn Press, London.

10. Lynch J (2008) Debate in Peace Journalism. Sydney University Press, Sydney.

11. Ibrahim SS, Lynch J, Hackett RA (2011) Expanding Peace Journalism: Comparative and Critical Approaches. Sydney University Press, Sydney.

12. Peleg S (2007) In defense of Peace Journalism: A Rejoinder: Conflict \& Communication Online 6: 1-9.

13. Goretti LN (2007) Peace Journalism Applied: An Assessment of Media Coverage of the Conflict in Northern Uganda. Conflict \& Communication Online. 6: 1-9.
14. Shinar D (2007) Epilogue: Peace Journalism - the State of the Art: Conflict and Communication Online, 6: 1-9.

15. Hanitzsch T (2004) Journalists as Peacekeeping Force? Peace Journalism \& Mass Communication Theory. Journalism Studies 5: 483-495.

16. Tehranian M, Ross SD (2009) Peace Journalism in Time of War. Transaction Publisher, New Brunswick.

17. Herman ES, Chomsky N (1988) Manufacturing Consent: The Political Economy of the Mass Media. New York, Pantheon Books.

18. Tehranian M (2002) Peace Journalism: Negotiating Global Ethics. Peace Culture and Communication Commission (PCC).

19. Kuusik N (2010) The Role of the Media in Peace Building, Conflict Management, and Prevention.

20. Loyn D (2007) Good Journalism or Peace Journalism - Counterplea: Conflict \& Communication Online. 6: 1-5.

21. Hackett RA (2006) Is Peace Journalism possible? Three Frameworks for Assessing Structure and Agency in News Media, Conflict and Communication Online 5: 1-13.

22. Akinfeleye AA, Okoye EO (2003) Issues in Nigeria Media History, 1900-2000AD. University of Lagos, Malthouse Press Limited.

23. Nwosu (2008) Communication for Health and Sustainable Development in Nigeria. Enugu, RhyceKerex Publishers.

24. Carter RF, Stamm KR, Heintz-Knowles K (1992) Agenda Setting and Consequentiality, Journalism\& Mass Communication Quarterly, 69: 868-877.

25. Centre for Conflict Resolution, South Africa.

26. Oyekanmi, Durojaiye F (2005) Development Crisis and Social Change, Lagos. 